\title{
KUNSKAP - UPPLEVELSE - PENGAR
}

Kring senaste årsskifte pågick en museidebatt i några svenska dagstidningar. Chefredaktören för Dagens Forskning, historikern Anders Björnsson, fann fyra huvudteman när han sammanfattade debatten i DIKforum (nr 9-03): museernas inriktning, samhällsrelevans, forskning och samlingar.

Samhällsrelevansen, det kanske övergripande temat, måste rimligtvis bejakas. Ett nät av offentliga museer blev under första hälften av 1900-talet ett accepterat samhällsåtagande. Inom ramen för 1970-talets svenska kulturpolitik följde en påtaglig professionalisering av museerna. Med stöd av statliga rapporter ställdes kvalitetskrav på samlande och samlingsvård, därmed på ökande ekonomiska insatser. Visandet och förmedlandet utvecklades, dels inom Riksutställningars särskilda uppdrag, dels genom en ökande skara museipedagoger. Museerna har erövrat en självklar roll som historiens hus, där medborgarna ska ha fri tillgång till historiska erfarenheter.

Dock - det samhällsekonomiska greppet hårdnar och olika lönsamhetskrav gör sig gällande. Samhällsrelevansen synas: forskningsuppdraget är omtvistat, även sedan den basverksamhet som kallats samlande/dokumentation döpts om till kunskapsuppbyggnad och makar museerna närmare eftertraktad forskningsstatus. Samlingsvård och trygg förvaring borde måhända anförtros specialistinstitutioner. Återstår visningsuppgiften - vad söker egentligen besökaren i museet?

Begreppen kunskap och bildning har länge varit honnörsord i myndighetsförväntningarna på museet, mot dem ställs i debatten gärna begreppet upplevelse. För de flesta politiker på olika nivåer är det i högtidstalen bildningsuppgiften som gäller, men detta kan i praktiken mer vara en munnens bekännelse. Museer som kan erbjuda upplevelser med lockelsen hos det unika och dyrbara, eller i dramatiska scenografier drar mer publik, något som politikerna kan anse bättre motsvara deras satsningar, eller som ger inkomster åt avgiftsbelagda historiehus. Även om kunskapssökandet - med Tage Danielssons ord - tillhör livets mer krävande glädjeämnen, måste den trötta läxan från otaliga symposier, seminarier och samkväm kring den falska dikotomin repas opp igen. Ett upplevelseskapande språk - visuellt och verbalt - är på ett oöverträffat sätt kunskapsbärande. Traditionen från den epok då museer etablerades som forskningsinstitutioner är visserligen seg. Dock är erfarenheterna positiva i museer 
som vågat satsa på den visuella och performativa förmedlingen, den som bygger på beställning hos och samverkan med externa forskare, museer som rationaliserar sin dataförmedling i välfungerande faktarum och utvecklar den visuella kunskapsgestaltningen tillsammans med specialister som konstnärer, formgivare, scenografer, arkitekter etc. Historiens hus har sin uppgift i att ge historiska perspektiv på samtiden och, omvänt, en historieförståelse grundad på nuerfarenhet. Allt konkretiserat i reflexiva utställningar med stöd av den fysiska kulturarvsmassans mängd av föremål och kulturminnen. Museet borde, som Erik Hofrén föreslagit, kunna arbeta med en redaktion som erbjuder historisk medvetenhet och reflektion i nuets förvirring.

När samhällsekonomin krymper på inkomstsidan och växer på utgiftssidan, finns en smygande oro för att museerna ska halka ner på makthavarnas prioriteringslistor. Lokal- och personalkostnader kan kanske täckas, men kunskapsuppbyggnaden, kulturarvsvården och den inspirerande erfarenhetsförmedlingen stagnerar, när all tid och kraft går åt för att skaffa sponsormedel för själva verksamheten.

I Nordisk Museologi, som härmed börjar sin elfte årgång, inleder Beate Federspiel med att teckna konturerna av museikonservatorns/samlingsvårdarens professionalisering. Bjarne Sode Funch visar hur publikundersökningar kan förfinas med fenomenologisk analys. Därefter följer en serie texter som mer av en slump kommit att bilda en museihistorisk exposé: Lennart Palmqvist skriver om antikens 'utställningar', Anne Aurasmaa om en 'minnesteater' under renässansen, Mattias Bäckström om hur tidens kulturarvsidéer avspeglas i utställningar från fyra skilda epoker, Eric Hedqvist slutligen om utställningen från 1920-talet i Göteborgs naturhistoriska museum som ett museografiskt minnesmärke.

En beskrivning av lokalmuseernas roll i Uleåborg-regionen i norra Finland, en undersökning utförd av två doktorander i Jyväskylä, Nina Rinta-Porkkonen \& Saija Ylitalo, samt Lova Kempes närstudie av tre dräktutställningar visar till två andra viktiga museologiska områden. Line Hjorth har gjort sig mödan att gå igenom kvarlåtenskapen efter seminarie- och konferenscykeln 'Museum 2000', som nu föreligger i en mäktig volym med samma namn, och försöker avlyssna en grundton i den kakofoniska kören av deltagarröster. Sista ordet ges i klassikertexten åt den för några år sedan bortgångne Ingemar Tunander, en de små museernas talesman. 